\title{
Vertical Profiles of Acetylene in the Troposphere and Stratosphere
}

\author{
J. RUDOLPH, D. H. EHHALT, and A. KHEDIM
}

\begin{abstract}
Stratospheric measurements of acetylene up to altitudes of $30 \mathrm{~km}$ are presented. The air samples were collected during three different balloon flights, two of them at $44^{\circ} \mathrm{N}$, one at $32^{\circ} \mathrm{N}$ using balloon borne, liquid neon-cooled, cryosamplers. Their acetylene concentration was measured in the laboratory by flame ionisation gaschromatography. The different profiles at $32^{\circ} \mathrm{N}$ and $44^{\circ} \mathrm{N}$ are discussed with respect to possible vertical exchange processes and compared with published model calculations.
\end{abstract}

Key words. Acetylene, stratospheric profiles, trace gas measurements, stratosphere-troposphere exchange.

\section{Introduction}

Light hydrocarbons are released exclusively at the Earth's surface and some are sufficiently longlived in the troposphere to mix into the stratosphere in measurable quantities. They are destroyed mostly by reaction with $\mathrm{OH}$ and $\mathrm{Cl}$ radicals, to some extent also by $\mathrm{O}^{1} \mathrm{D}$. Consequently the vertical stratospheric profiles of light hydrocarbons are determined by vertical transport and the stratospheric vertical profiles of these radical species. Thus stratospheric profiles of light hydrocarbons can be used to obtain information on the stratospheric exchange parameters or vertical distributions of radicals. For instance, profiles of the vertical eddy diffusion coefficient were derived from the average $\mathrm{CH}_{4}$ profile (Wofsy and McElroy, 1973; Ehhalt et al., 1974, 1975). The vertical distribution of $\mathrm{C}_{2} \mathrm{H}_{6}$ was utilized to estimate the concentration of $\mathrm{Cl}$-atoms in the lower stratosphere (Rudolph et al., 1981a).

In this paper we report measurements of acetylene $\left(\mathrm{C}_{2} \mathrm{H}_{2}\right)$ in the stratosphere. This compound exhibits a strong latitudinal gradient in the troposphere, with mixing ratios which are by a factor of 5-10 lower in the tropics than at mid-northern latitudes, a fact which can be utilized to gain additional information about the latitude at which tropospheric air entered the stratosphere.

\section{Experimental}

Whole air samples were collected by balloon borne, liquid neon-cooled cryosamplers in 
the stratosphere. Two samplers of similar construction were employed; both samplers followed the design described by Lueb et al. (1975). Tropospheric air samples were collected in evacuated all-stainless steel containers aboard an airplane. Immediately after the balloon flights, the air samples were transferred to special electropolished stainless steel containers of 0.5 or $2 \mathrm{dm}^{3}$ volume and transported into the laboratory for gaschromatographic analysis.

The hydrocarbons were concentrated on a precolumn at subambient temperatures (sample volume between 1 and 51 STP), separated on a column packed with porous silica, and detected with a flame ionisation detector. The analytical procedure is very similar to that described by Rudolph et al. (1981b). The measurements were quantitated by comparison with a secondary air standard. This secondary standard was calibrated with mixtures of $0.1-2 \mathrm{ppb}$ of $\mathrm{C}_{2} \mathrm{H}_{2}$ in synthetic air. These mixtures were prepared by two or three step static dilution. Short-time variations of the absolute calibration are less than $10 \%$, long-time drift of the secondary standard for $\mathrm{C}_{2} \mathrm{H}_{2}$ does not exceed $15 \% / \mathrm{yr}$ and was corrected by repeated absolute calibrations.

Both the detection limit and the analytical precision of the $\mathrm{C}_{2} \mathrm{H}_{2}$ measurements depended strongly on the sample volume which was available for the gaschromatographic determinations. The sample volume which was available for the $\mathrm{C}_{2} \mathrm{H}_{2}$ measurements from the two flights in 1979, often did not exceed 11 of air at standard temperature and pressure. The corresponding detection limit was $0.015-0.02 \mathrm{ppb}(2 \sigma)$, precision of the analysis for mixing ratios well above the lower limit of detection was better than $10 \%$. From the flight in 1981, much larger volumes of air were available and the volume employed for $\mathrm{C}_{2} \mathrm{H}_{2}$ analysis was 3-51 STP. Accordingly, the detection limit was significantly lower (0.003-0.005 ppb) and the analytical precision for low mixing ratios better. The detection limits were calculated from twice the baseline noise level $(2 \sigma)$ and the sample volume.

\section{Results}

Approximately 30 stratospheric whole air samples were collected during three balloon flights. Two of these flights - on 16 and 28 June 1979 - were part of a joint project of the Max-Planck-Institut für Chemie in Mainz, the Max-Planck-Institut für Aeronomie in Lindau and the Institut für Atmosphärische Chemie in Jülich. Both of these flights were launched from Gap, Southern France, $\left(44^{\circ} \mathrm{N}, 2^{\circ} \mathrm{E}\right)$. The sampler employed for these two balloon flights allowed for the collection of up to eight air samples per flight. During the balloon flight on 16 June, several tropospheric air samples were also collected aboard an airplane. A third flight was made in cooperation with the National Center of Atmospheric

Research (NCAR), Boulder. It was launched from Palestine, Texas $\left(32^{\circ} \mathrm{N}, 96^{\circ} \mathrm{W}\right.$ ) on 20 September 1981. That cryosampler was suitable for the collection of up to 16 air samples. The vertical profiles of $\mathrm{C}_{2} \mathrm{H}_{2}$ obtained from all three flights are shown in Figure 1.

The data contain one point (at $29 \mathrm{~km}$ altitude during the flight on $16 \mathrm{June}$ ) which is significantly higher than the value found for the next sample below. This points to contamination. On the other hand, this straggling point cannot be ascribed to a general 


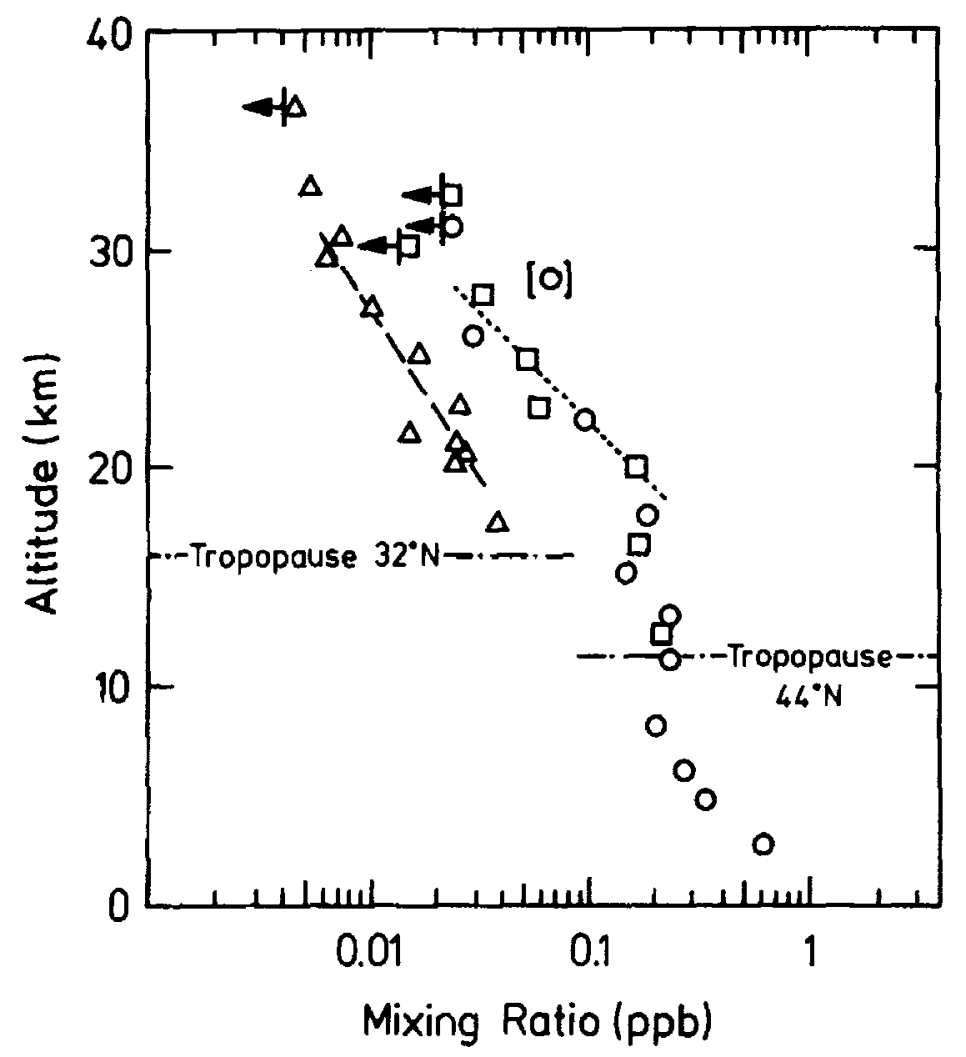

Fig. 1. Vertical profiles of acetylene mixing ratios in the troposphere and stratosphere. Circles: 16 June 1979 at $44^{\circ} \mathrm{N} / 2^{\circ} \mathrm{E}$ Squares: 28 June 1979 at $44^{\circ} \mathrm{N} / 2^{\circ} \mathrm{E}$, Triangles: $20-21$ September 1981 at $32^{\circ} \mathrm{N} / 96^{\circ} \mathrm{W}$. Dotted line: least square fit to exponential profile for data from $44^{\circ} \mathrm{N}$ for $20-30 \mathrm{~km}$ altitude, data point in brackets is possibly contaminated. Dashed line: same as dotted line, but for data from $32^{\circ} \mathrm{N}$. Points with a left arrow represent the detection limit for those samples where $\mathrm{C}_{2} \mathrm{H}_{2}$ could not be detected.

contamination problem because the next higher samples from the same flight had $\mathrm{C}_{2} \mathrm{H}_{2}$ mixing ratios below the limit of detection (see Figure 1). The extent of contamination during that flight can be estimated, assuming that the lower limit of detection of 0.015$0.02 \mathrm{ppb}$ represents the actual $\mathrm{C}_{2} \mathrm{H}_{2}$-concentration in the uppermost samples and that this concentration is solely due to a systematic contamination in the sampling tubes. This allows to calculate upper limits for the contribution of contamination to the samples from lower altitudes. They amount to $10 \%$ or less for samples from below $20 \mathrm{~km}, 30 \%$ for samples from $20-25 \mathrm{~km}$, and up to $50 \%$ for samples from $25-30 \mathrm{~km}$. Thus, significant contamination cannot be ruled out completely above $25 \mathrm{~km}$ and the gradient of the experimental profiles above $\approx 25 \mathrm{~km}$ may be too small owing to contamination effects. However, for altitudes below $25 \mathrm{~km}$, such contaminations should only be of marginal influence.

\section{Discussion}

The vertical $\mathrm{C}_{2} \mathrm{H}_{2}$ profiles from the two flights in June 1979 for $44^{\circ} \mathrm{N}$ agree within the 
scatter of the experimental data. Since this scatter is approximately of the same magnitude as the analytical uncertainties of the individual measurements, smaller structures of the profiles or variations between the two flights cannot be distinguished from the experimental errors. Nevertheless, the general shape of the stratospheric and tropospheric $\mathrm{C}_{2} \mathrm{H}_{2}$ vertical profile is quite well defined for these two flights.

There is already a significant decrease of the $\mathrm{C}_{2} \mathrm{H}_{2}$ mixing ratios in the lower and middle troposphere. These samples were collected over continental Europe and the $\mathrm{C}_{2} \mathrm{H}_{2}$ mixing ratios in the lower troposphere are likely to be influenced by local or regional sources. Between 5 and $13 \mathrm{~km}$ altitude the $\mathrm{C}_{2} \mathrm{H}_{2}$ mixing ratios remain nearly constant at about $0.2 \mathrm{ppb}$. Moreover, the $\mathrm{C}_{2} \mathrm{H}_{2}$ gradient in the lower stratosphere is very weak, with a scale height of $26 \pm 14 \mathrm{~km}$ so that the region of nearly constant mixing ratio extends to about $20 \mathrm{~km}$ altitude. Above $20 \mathrm{~km}$ altitude, there is a quite steep gradient for $\mathrm{C}_{2} \mathrm{H}_{2}$ : the scale height - omitting the straggling point at $29 \mathrm{~km}-$ is $4.5 \mathrm{~km}$ $\pm 0.8 \mathrm{~km}$. The $\mathrm{C}_{2} \mathrm{H}_{2}$ mixing ratios around $27 \mathrm{~km}$ are about $0.03 \mathrm{ppb}$, and less than 0.02 ppb above $30 \mathrm{~km}$.

A quite different picture is presented by the vertical distribution of $\mathrm{C}_{2} \mathrm{H}_{2}$ at $32^{\circ} \mathrm{N}$. Essentially, from the tropopause upwards, the $\mathrm{C}_{2} \mathrm{H}_{2}$ mixing ratios decrease considerably: from $0.04 \mathrm{ppb}$ at $17 \mathrm{~km}$ to $\approx 0.005 \mathrm{ppb}$ at $32 \mathrm{~km}$ altitude with a fairly constant scale height. With $6.8 \pm 1.2 \mathrm{~km}$ between $20-30 \mathrm{~km}$ altitude, the scale height is slightly larger than at $44^{\circ} \mathrm{N}$ for the same altitude range. Especially interesting is the observation that the stratospheric $\mathrm{C}_{2} \mathrm{H}_{2}$ mixing ratios at $32^{\circ} \mathrm{N}$ are lower than those at $44^{\circ} \mathrm{N}$ by a factor of about 4.

There are no other measurements of vertical $\mathrm{C}_{2} \mathrm{H}_{2}$ profiles in the stratosphere we know of. But a few data are available on the $\mathrm{C}_{2} \mathrm{H}_{2}$ mixing ratio in the upper troposphere and lower stratosphere which can be compared to our measurements. Robinson (1978) reported measurements of $\mathrm{C}_{2} \mathrm{H}_{2}$ made by Rasmussen and Robinson in the Northern and Southern Hemisphere over the Pacific both in the troposphere and in the lower stratosphere. Northern Hemispheric values $\left(25-75^{\circ} \mathrm{N}\right.$ ) are $0.2 \mathrm{ppb}$ (average from 9 samples) for the troposphere and $0.05 \mathrm{ppb}$ (8 samples) for the stratosphere just above the tropopause. The corresponding Southern Hemispheric data $\left(25^{\circ} \mathrm{S}-65^{\circ} \mathrm{S}\right)$ are $0.08 \mathrm{ppb}(17$ samples) and $0.03 \mathrm{ppb}$ (3 samples) respectively. Cronn and Robinson (1979) report $\mathrm{C}_{2} \mathrm{H}_{2}$ mixing ratios for the upper troposphere of $0.23 \pm 0.06 \mathrm{ppb}$ at $37^{\circ} \mathrm{N} / 123^{\circ} \mathrm{W}$ and $0.08 \pm 0.08 \mathrm{ppb}$ at $9^{\circ} \mathrm{N} / 80^{\circ} \mathrm{W}$. For the lower stratosphere (between 0.5 and $3 \mathrm{~km}$ above the tropopause) their data for $36-38^{\circ} \mathrm{N}$ range from $\approx 0.2 \mathrm{ppb}$ to below their detection limit of about $0.04 \mathrm{ppb}$. Both the measurements of Cronn and Robinson and of Rasmussen and Robinson were made by collection of pressurized whole air samples aboard an airplaine and subsequent gaschromatographic analysis.

Like the present measurements, the older data indicate a significant gradient with latitude. Also in absolute values these measurements compare favorably with our findings of $\approx 0.2 \mathrm{ppb} \mathrm{C}_{2} \mathrm{H}_{2}$ in the upper troposphere at $44^{\circ} \mathrm{N}$ and of $\approx 0.04 \mathrm{ppb}$ in the lower stratosphere at $32^{\circ} \mathrm{N}$. Our measurements in the lower stratosphere at $44^{\circ} \mathrm{N}$ are $\approx 0.2$ $\mathrm{ppb}$, significantly higher than the average value of $0.05 \mathrm{ppb}$ reported by Rasmussen and Robinson for $25-75^{\circ} \mathrm{N}$. 
There is one measurement of the $\mathrm{C}_{2} \mathrm{H}_{2}$ mixing ratio in the upper troposphere by an entirely different technique. Goldman et al. (1981) derived an acetylene mixing ratio of $0.025 \mathrm{ppb} \pm 40 \%$ for $\approx 9 \mathrm{~km}$ altitude from solar spectra obtained during a balloon flight. The flight was made on 21 March 1981 from Holloman Air Force Base in New Mexico $\left(35^{\circ} \mathrm{N}\right)$. This value is considerably lower than all the other published tropospheric $\mathrm{C}_{2} \mathrm{H}_{2}$ mixing ratios for this latitude. To a large extent, the latitudinal gradient observed in the upper troposphere and lower stratosphere is merely a reflection of the latitudinal gradient found at the surface which, in turn, reflects the distribution of the sources. Measurements in surface air over the Atlantic showed $\mathrm{C}_{2} \mathrm{H}_{2}$ mixing ratios of 0.3 to 0.4 $\mathrm{ppb}$ at mid-northern latitudes and a decrease from 0.3 down to $0.1-0.05 \mathrm{ppb}$ between $30^{\circ} \mathrm{N}$ and the equator (Rudolph and Ehhalt, 1981; Rudolph et al., 1982). A similar behaviour was reported for $\mathrm{C}_{2} \mathrm{H}_{2}$ in surface air over the Eastern Pacific with mixing ratios of $0.4 \mathrm{ppb}$ in the latitude range of $40^{\circ} \mathrm{N}-10^{\circ} \mathrm{N}$ and $0.1 \mathrm{ppb}$ in equatorial regions (Singh and Salas, 1982).

Because of its relatively short tropospheric lifetime of approximately 50 days, the mixing ratio of $\mathrm{C}_{2} \mathrm{H}_{2}$ also shows a vertical decrease in the troposphere. Combined with the latitudinal gradient, this should generate a two-dimensional concentration field where the lines of constant mixing ratio slope upward and northward. Thus, the latitudinal gradient in the upper troposphere should be shifted to northern latitudes. Such a behaviour has indeed been observed during the STRATOZ II flight of the French Caravelle research aircraft in April and May 1980 (Rudolph et al., 1984).

The present measurements can also be compared to predictions of the vertical stratospheric $\mathrm{C}_{2} \mathrm{H}_{2}$ profile from one dimensional steady state models (Chameides and Cicerone, 1978; Goldman et al., 1981). Such predictions were carried for $30^{\circ} \mathrm{N}$ and equinox conditions, and are thought to represent average stratospheric profiles. Examples of these calculations are shown in Figure 2 together with our measurements at $32^{\circ} \mathrm{N}$. For better comparison the model profiles were scaled to a groundlevel mixing ratio of $0.3 \mathrm{ppb}$, the value found over the Atlantic at $30^{\circ} \mathrm{N}$ (Rudolph et al., 1982). The two model profiles exhibit large differences. Since in both models the profiles of the vertical eddy diffusion coefficient are nearly identical and since the destruction of $\mathrm{C}_{2} \mathrm{H}_{2}$ by $\mathrm{Cl}$ atoms is treated as a minor loss in both, the differences in the predicted profiles must be due to the way the reaction of $\mathrm{OH}$ with $\mathrm{C}_{2} \mathrm{H}_{2}$ is modelled. Indeed, from the many different rate constants published for this reaction (e.g., Breen and Glass, 1970; Smith and Zellner, 1973; Davis et al., 1975; Perry et al., 1977; Michael et al., 1980) Goldman et al. (1981) selected the high pressure limiting rate constant $6.8 \times 10^{-12} \exp (-646 / T) \mathrm{cm}^{3} / \mathrm{s}^{-1}$ molecule ${ }^{-1}$ of Michael et al. (1980), whereas Chameides and Cicerone (1978) used the much slower rate constant of $5.3 \times 10^{-12} \exp (-1000 / T) \mathrm{cm}^{3} / \mathrm{s}^{-1}$ molecule ${ }^{-1}$ given by Breen and Glass (1970). The vertical profiles of $\mathrm{OH}$ in the two models also differ - in shape and absolute value. The $\mathrm{C}_{2} \mathrm{H}_{2}$ profile by Goldman et al. (1982) shown in Figure 2 is their example for 'low OH'. It utilized an $\mathrm{OH}$ concentration profile which is between 14 and $26 \mathrm{~km}$ altitude about a factor of 2 lower than that used by Chameides and Cicerone (1978). Still the lower $\mathrm{OH}$ concentrations do not compensate for the faster rate constant used by Goldman et al. (1982) and the $\mathrm{C}_{2} \mathrm{H}_{2}$ profile predicted by their model decreases 


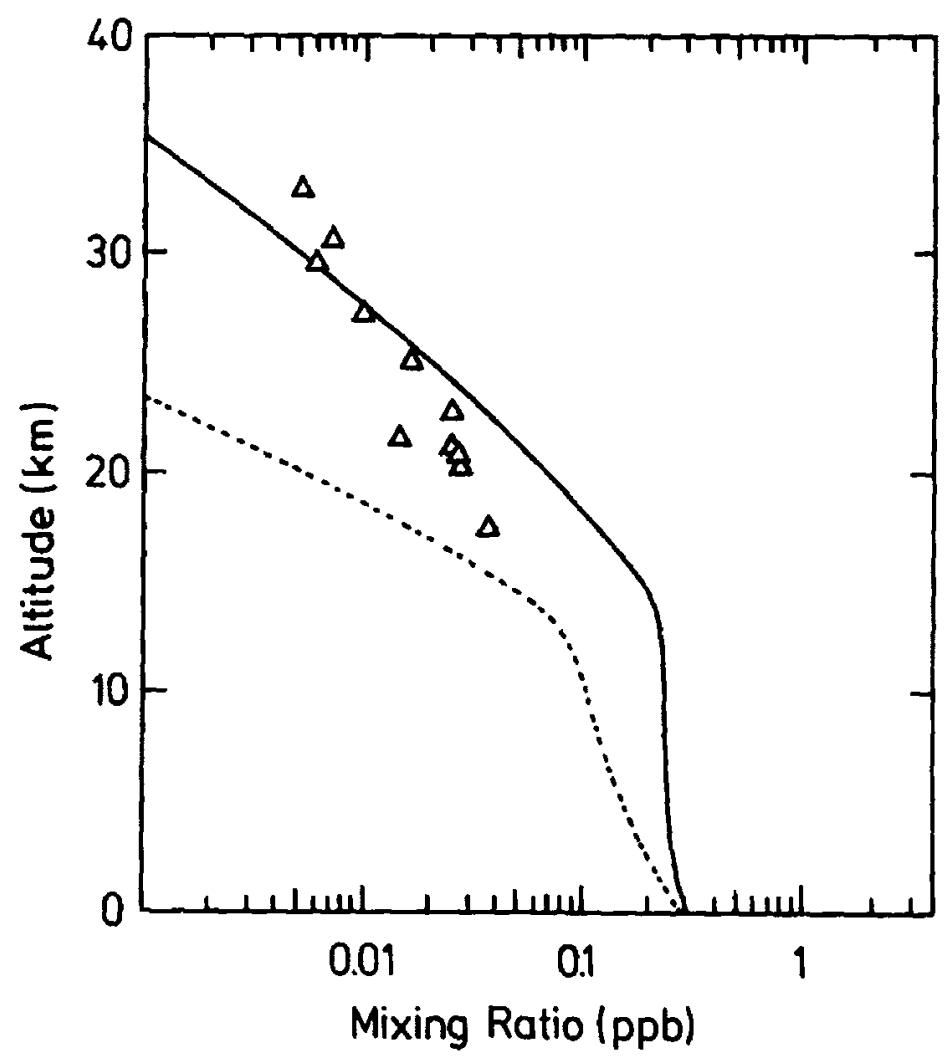

Fig. 2. Comparison of model calculations for $30^{\circ} \mathrm{N}$ and equinox with measurement at $32^{\circ} \mathrm{N}$. Triangles: measurements. Dashed line: model predictions of Goldman et al. (1981) for low OH, scaled to $0.3 \mathrm{ppb}$ groundlevel mixing ratio. Solid line: Model predictions of Chameides and Cicerone (1979) scaled to $0.3 \mathrm{ppb}$ groundlevel mixing ratio.

much more rapidly with altitude. The fact that Goldman et al. (1982) terminated their calculations at $26 \mathrm{~km}$ altitude using a flux boundary condition seems to have little influence on the $\mathrm{C}_{2} \mathrm{H}_{2}$ mixing ratios below $24 \mathrm{~km}$ altitude shown in Figure 2. The observed stratospheric gradient is significantly smaller than those predicted by both models, although the model profile of Chameides and Cicerone compares much better with the measurements. In view of the fact that a single measured vertical trace gas profile represents a more or less instantaneous and local picture of the stratosphere, which could differ considerably from the average conditions, it appears premature to draw far reaching conclusions from such a comparison with one-dimensional models. Nevertheless, taken together with the two $\mathrm{C}_{2} \mathrm{H}_{2}$ profiles at $44^{\circ} \mathrm{N}$, the low stratospheric $\mathrm{C}_{2} \mathrm{H}_{2}$ gradient observed at $32^{\circ} \mathrm{N}$ provides a strong indication that the use of the high pressure limiting rate constant of Michael et al. (1980) causes too high destruction rates of $\mathrm{C}_{2} \mathrm{H}_{2}$ in the stratosphere and is therefore inappropriate.

Regarding the profiles measured at $44^{\circ} \mathrm{N}$, the observation of nearly constant $\mathrm{C}_{2} \mathrm{H}_{2}$ mixing ratios of $0.15-0.2 \mathrm{ppb}$ in the icwer stratosphere up to $20 \mathrm{~km}$ altitude clearly demands processes which incorporate tropospheric air into the lower stratosphere in a relatively rapid way. Comparable effects have been observed in vertical profiles of methane 
for the same latitude and ascribed to the tropospheric-stratospheric exchange during tropopause folding events. For acetylene, the strong latitudinal gradient in the troposphere also helps to locate the origin of the air in the lower stratosphere. With nearly $0.2 \mathrm{ppb}$ of $\mathrm{C}_{2} \mathrm{H}_{2}$ that air could originate only from a latitude range between $15^{\circ} \mathrm{N}$ to $75^{\circ} \mathrm{N}$ (cf. Rudolph et al., 1982). Future measurements especially in the upper troposphere might refine that range. At present we have to keep in mind that $\mathrm{C}_{2} \mathrm{H}_{2}$, due to its average tropospheric lifetime of only 50 days (Chameides and Cicerone, 1978), may also exhibit substantial seasonal variations both in the stratosphere and troposphere.

\section{Conclusions}

The latitudinal variation of acetylene at groundlevel has significant influences on the stratospheric $\mathrm{C}_{2} \mathrm{H}_{2}$ distribution. Thus one-dimensional models are only of limited value for the interpretation of stratospheric $\mathrm{C}_{2} \mathrm{H}_{2}$ profiles, since in addition to vertical exchange processes horizontal transport must be considered. Owing to the large latitudinal gradient in the tropospheric $\mathrm{C}_{2} \mathrm{H}_{2}$ mixing ratios additional insight in the origin of the stratospheric air masses can be gained from the measurement of stratospheric $\mathrm{C}_{2} \mathrm{H}_{2}$ mixing ratios. Thus, it can be argued that the high $\mathrm{C}_{2} \mathrm{H}_{2}$ mixing ratios observed in the lower stratosphere at $44^{\circ} \mathrm{N}$ demand fast exchange with tropospheric air from latitudes with sufficiently high $\mathrm{C}_{2} \mathrm{H}_{2}$ mixing ratios - i.e., from $15-75^{\circ} \mathrm{N}$ latitude. It is important to remember that -- due to its comparably short atmospheric lifetime $-\mathrm{C}_{2} \mathrm{H}_{2}$ will respond to changes of the stratospheric $\mathrm{OH}$ distribution or transport much faster than longer lived trace gases as $\mathrm{CH}_{4}$. Thus individual $\mathrm{C}_{2} \mathrm{H}_{2}$ profiles may exhibit much more pronounced deviations from the average and inferences drawn from such individual profiles are first of all applicable to the given situation. On the other side this fact may be used to study the variability of processes in the lower stratosphere. Consequently measurements of the stratospheric $\mathrm{C}_{2} \mathrm{H}_{2}$ distribution can provide interesting information on transport and considering its rather simple stratospheric chemical destruction - may be used as a valuable tool for the test of two-dimensional chemical models of the stratosphere.

\section{Acknowledgements}

We would like to thank P. Fabian of the Max-Planck-Institut of Aeronomie in Lindau who made available the stratospheric samples from $44^{\circ} \mathrm{N}$ latitude and $\mathrm{W}$. Seiler of the Max-Planck-Institut für Chemie who made available the tropospheric samples. Likewise, we thank L. Heidt from the National Center of Atmospheric Research who provided the stratospheric samples from $32^{\circ} \mathrm{N}$ latitude. This work was partly financed by the Bundesminister für Forschung und Technologie of the Federal Republic of Germany.

\section{References}

Breen, J. E. and Glass, G. P., 1970, The reaction of the hydroxyl radical with acetylene, Int. J. Chem. Kinet. 3, 145-153. 
Chameides, W. L. and Cicerone, R. J., 1978, Effects of nonmethane hydrocarbons in the atmosphere, J. Geophys. Res. 83, 947-952.

Cronn, D. and Robinson, E., 1979, Tropospheric and lower stratospheric profile of ethane and acetylene, Geophys. Res. Lett. 6, 641-644.

Davis, D. D., Fischer, S., Schiff, R., Watson, R. T., and Bollinger, W., 1975, A kinetics study of the reaction of $\mathrm{OH}$ radicals with two $\mathrm{C}_{2}$ hydrocarbons: $\mathrm{C}_{2} \mathrm{H}_{4}$ and $\mathrm{C}_{2} \mathrm{H}_{2}, J$. Chem. Phys. 63, 17071712.

Ehhalt, D. H., Heidt, L. E., Lueb, R. H., and Roper, N., 1974, Vertical profiles of $\mathrm{CH}_{4}, \mathrm{H}_{2}, \mathrm{CO}, \mathrm{N}_{2} \mathrm{O}$ and $\mathrm{CO}_{2}$ in the stratosphere, Proc. of Third Conference on CIAP, Feb. 28-March 2, 1974, Cambridge, Mass, pp. 153-260.

Ehhalt, D. H., Heidt, L. E., Lueb, R. H., and Pollock, W., 1975, The vertical distribution of trace gases in the stratosphere, Pure Appl. Geophys. 113, 389-402.

Ehhalt, D. H. and Tönnißen, A., 1979, Hydrogen and carbon compounas in the stratosphere, Proceedings of the NATO Advanced Study Institute on Atmospheric Ozone: Its Variation and Human Influences, Aldeia das Acoteias, Portugal, Rep. FAA-EE-80-20, 129-151, Fed. Aviat. Admin., Washington, D.C.

Goldman, A., Murcray, F. J., Blatherwick, R. D., Gillis, J. R., Bonomo, F. S., Murcray, F. H., Murcray, D. G., and Cicerone, R. J., 1981, Identification of acetylene in infrared atmospheric absorption spectra, J, Geophys. Res. 86, 12143-12146.

Lueb, R. A., Ehhalt, D. H., and Heidt, L. E., 1975, Balloon borne low temperature air sampler, Rev. Sci. Instr. 46, 702-705.

Michael, J. V., Nava, D. F., Borkowski, R.P., Payne, W. A., and Stief, L. J., 1980, Pressure dependence of the absolute rate constant for the reaction $\mathrm{OH}+\mathrm{C}_{2} \mathrm{H}_{2}$ from 228 to $413 \mathrm{~K}, J$. Chem. Phys. 73, 6108-6116.

Perry, R. A., Atkinson, R., and Pitts, J. N., Jr., 1977, Kinetics of the reactions of OH radicals with $\mathrm{C}_{2} \mathrm{H}_{2}$ and $\mathrm{CO}, \mathrm{J}$. Chem. Phys. 67, 5577-5584.

Robinson, E., 1978, Hydrocarbons in the atmosphere, Pure Appl. Geophys. 116, 372-384.

Rudolph, J., Ehhalt, D. H., Khedim, A., and Jebsen, C., 1982, Latitudinal profiles of some $\mathrm{C}_{2}-\mathrm{C}_{s}$ hydrocarbons in the clean troposphere over the Atlantic, Preprint Volume: Second Symposium on the Composition of the Nonurban Troposphere, May 25-28, 1982, Williamsburg, Va., American Meteorological Society, Boston, Mass., pp. 284-286.

Rudolph, J. and Ehhalt, D. H., 1981, Measurements of $\mathrm{C}_{2} \cdot \mathrm{C}_{5}$ hydrocarbons over the North Atlantic, J. Geophys. Res. 86, $11959-11964$.

Rudolph, J., Ehhalt, D. H., and Tönnißen, A., 1981a, Vertical profiles of ethane and propane in the stratosphere, J. Geophys. Res. 86, 7267-7272.

Rudolph, J., Ehhalt, D. H., Khedim, A., and Jebsen, C., 1981 b, Determination of $C_{2}-C_{3}$ hydrocarbons in the atmosphere at low parts per $10^{-9}$ to high $10^{-12}$ levels, J. Chromatogr. 271, 301-310.

Rudolph, J., Schmidt, U., Khedim, A., Kulessa, G., Meixner, F., and Ehhalt, D. H., 1984, Latitudealtitude cross sections of the mixing ratio of light hydrocarbons during STRATOZ II flight, in preparation.

Singh, H. B. and Salas, L. J., 1982, Measurement of selected light hydrocarbons over the Pacific Ocean: latitudinal and seasonal variations, Geophys. Res. Lett. 9, 842-845.

Smith, J. W. M. and Zellner, R., 1973, Rate measurements of reaction of $O H$ by resonance adsorption, Part 2: Reactions of $\mathrm{OH}$ with $\mathrm{CO}, \mathrm{C}_{2} \mathrm{H}_{4}$ and $\mathrm{C}_{2} \mathrm{H}_{2}, J$. Chem. Soc. Faraday Trans. II 69, 16171627.

Wofsy, S. C. and McElroy, M. B., 1973, On vertical mixing in the upper stratosphere and lower mesosphere, J. Geophys. Res. 78, 2619-2624. 